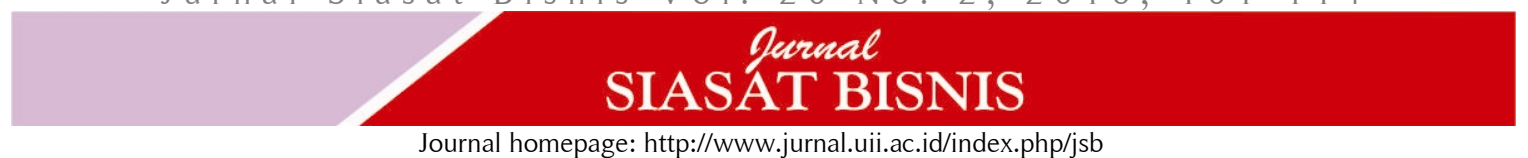

Journal homepage: http://www.jurnal.uii.ac.id/index.php/jsb

\title{
The Effect of Social Network, Funding and Productive Organizational Energy on the Capability of Organizational Ambidexterity in Research Institution
}

\author{
Novita Dyah*1, Rangga Almahendra ${ }^{2}$ \\ 1,2 Universitas Gadjah Mada Yogyakarta \\ Department Management, Faculty of Economics and Business \\ Jl Sociohumaniora, Bulaksumur, Yogyakarta, Indonesia \\ +62 274548510 Ext 260 \\ *Correspondence author e-mail: novita.dyah@gmail.com \\ e-mail: 99rangga@gmail.com; almahendra@ugm.ac.id
}

\begin{abstract}
The concept of organizational ambidexterity has been resonated and applied in diverse areas of management research. When establishing its strategic direction, research institutions are confronted with strategic tradesoffs, namely balancing the right amounts of exploration of new knowledge and exploitation of existing knowledge in their research orientation. We investigate this trade-off by building on the notion that research institution need to reconcile the paradoxical demands of exploitation and exploration in their orientation. The objective of this study is to examine the effect of social network, funding, and productive organizational energy on knowledge exploration, knowledge exploitation and the capability of organizational ambidexterity in the context of research institution. A sample of 130 research institutions such as laboratory, study center and training center was collected through questionnaire survey. We tested the hypotheses using Partial Least Square (PLS). Findings of the study indicate that social network and funding are positively related to knowledge exploration and exploitation. However, productive organizational energy has no positive effect on knowledge exploration and exploitation. It is also confirmed that knowledge exploration and knowledge exploitation have a significant influence on the capability of organizational ambidexterity, but knowledge exploitation has a dominant role on that effect.
\end{abstract}

Keywords: funding and productive organizational energy, knowledge exploration, knowledge exploitation, organizational ambidexterity, social network

\begin{abstract}
Abstrak
Konsep ambideksteritas organisasi telah lama bergaung dan diaplikasikan di berbagai penelitian manajemen. Dalam pengembangan arah strategisnya, lembaga penelitian seringkali dihadapkan pada strategi trade-off, yaitu keputusan untuk menyeimbangkan antara eksplorasi pengetahuan baru dan ekploitasi pengetahuan yang telah ada. Kami meneliti strategi trade-off ini dengan membangun gagasan bahwa lembaga penelitian perlu untuk merekonsiliasi kebutuhan ekploitasi dan ekplorasi dalam orientasi penelitian mereka. Tujuan penelitian ini adalah untuk menguji pengaruh jaringan sosial, pendanaan dan energi organisasi produktif terhadap eksplorasi pengetahuan, ekploitasi pengetahuan dan kemampuan ambideksteritas organisasi dalam konteks lembaga penelitian. Sampel terdiri dari 130 lembaga penelitian yang terdiri dari laboratorium, pusat studi dan pusat pelatihan. Data dikumpulkan menggunakan kuesioner dan hipotesis diuji menggunakan Partial Least Square (PLS). Hasil pengujian menunjukkan bahwa jaringan sosial dan pendanaan berpengaruh positif terhadap eksplorasi dan eksploitasi pengetahuan, sedangkan energi organisasi produktif tidak berpengaruh positif terhadap eksplorasi dan eksploitasi pengetahuan. Selain itu, eksplorasi dan eksploitasi pengetahuan memiliki pengaruh signifikan terhadap pembentukan kemampuan ambideksteritas organisasi, tetapi ekploitasi pengetahuan memiliki peran yang lebih dominan.
\end{abstract}

Kata kunci: ambidekteritas organisasi, eksplorasi pengetahuan, eksploitasi pengetahuan, energi organisasi produktif dan pendanaan, jejaring sosial.

JEL: L14, L20, L21, L31

DOI: 10.20885/jsb.vol20.iss2.art1 


\section{Introduction}

Although there has been abundant accumulation of researches focusing on organization ambidexterity (Tushman \& O'Reilly, 1997; He \& Wong, 2004; Gibson \& Birkinshaw, 2004) these growths of studies apparently do not significantly ensure a consolidation of knowledge. Research on ambidexterity hypothesis has been often characterized as diverse, fragmented, and still being in ferment ( $\mathrm{Li}$, Vanhaverbeke \& Schoenmakers, 2008).

As the popularity of this phrase grew further, researchers have been attempted to address this issue from many different perspectives. Recently, scholars used the term of ambidextrous organization to address firms ability to simultaneously perform two conflicting dilemmas of exploration and exploitation (March, 1991).

Exploration and exploitation of knowledge itself is known to provide many benefits for the survival of the organization. Previous research has shown that organizational learning capabilities, including the exploration and exploitation of knowledge is the main source of competitive advantage (Kogut and Zander, 1992; Prahalad and Hamel, 1990; Liu, 2006). The study also mentions that an appropriately manage of balancing between exploration and exploitation becomes a major factor that can support the survival and prosperity of organization (March, 1991; Cohen and Levinthal, 1990; Levinthal and March, 1993).

Awareness of the importance and need for exploration and exploitation as well as maintaining a balance between the two is the basis for the formation of ambidexterity strategy, which is proposed as a solution to achieve such balance (Benner and Tushman, 2003). Ambidexterity refers to synchronize the activities of exploration and exploitation through merger or separation of sub-units or individuals, which each specialize in either exploration or exploitation and do both simultaneously (Gupta et al., 2006). Ambidextrous organization - the term for organizations that have the ability to apply ambidexterity - can be a champion because they are able to recognize opportunity, linkages and synergies between exploration and exploitation activities (Smith and Tushman, 2005).

The process of exploration and exploitation of knowledge are influenced by several factors. In the context of research institution, previous studies mentioned external factors such as social networks (McFadyen and Cannella, 2004; Rotolo and Petruzzelli, 2012) and funding (Connolly, 1997; Hottenrott and Thorwarth, 2010; Hottenrott and Lawson, 2012) to be a factor that affect the creation of new knowledge through research productivity. Organization stickiness in a network of relationships with other organizations is known to have significant implications for organizational performance (Gulati et al., 2000; Zaheer and Bell, 2005). Organizations that have superior external network will have a better ability to exploit internal capabilities as well as having a broad access to new knowledge for the exploration (Zaheer and Bell, 2005).

Funding also can be a factor that is important for the exploration and exploitation of knowledge. This factor is mentioned to affect the behavior of research of the institution, whether to produces pure knowledge as a result of exploration or applied knowledge as a result of exploitation (Hottenrott and Thorwarth, 2010). Funding from internal institutions generally produce more pure research because this fund is allocated to support the basic research (Siadat et al., 2012). Meanwhile, external funding is more likely to generate applied knowledge based on the agreement with the donors (Hottenrott and Lawson, 2012).

In addition, internal factors such as the collective behavior of individual in organizations also need to be accommodated to see its effect on exploration and exploitation activities. Individual daily behavior seems rooted in individual personality (Hofmann and Jones, 2005). Schudy (2010) assumed that an individual's personality or behavior of employees will form ambidextrous behavior. Previous studies have analyzed the idea of the daily behavior as one of the antecedents of ambidexterity, for example, Adler et al. (1999) which says that the meta-routines- a collective form of daily behavior - contribute to the ability to balance exploration and exploitation.

Güttel and Konlechner (2009) mention a specific norms and patterns of certain collective behavior support ambidexterity formation. Routines and norms that arise from everyday behavior of 
individuals, called personality, will transform into the collective level, referred to as the collective personality (Hofmann and Jones, 2005). Collective behavior is represented by the construct of productive organizational energy that includes three dimensions, named affective, cognitive and behavioral dimensions (Cole et al., 2012).

Affective dimension describe the collective positive emotion, enthusiasm and inspiration on job duties and organizational goals. Cognitive dimension refers to the collective ability to think and act in productive and proactive job-related tasks. Behavioral dimension reflects the collective behavior of agentic behavior to take advantage of opportunities, take risks and persistence in pursuit of goals and a willingness to change in order to adjust to the situation that is more in line with the interests, aspirations and expectations (Cole et al., 2012; Schudy, 2010).

Referring to that three factors: the social network, funding and productive organizational energy in exploration and exploitation activities, this study intends to examine the direct relationship of these factors on the exploration and exploitation of knowledge in relation to the creation of knowledge in research institutions. This study also intends to provide empirical evidence of the influence of these factors on the exploitation and exploration of knowledge and its implications for the formation of the organizational ambidexterity capability in research institutions.

\section{Literature Review and Hypotheses}

According to Nonaka and Takeuchi (1995), the conversion process between tacit knowledge and explicit knowledge are through four patterns of interactions: socialization, externalization, combination and internalization. Starting from the individual and then increased to a higher level and form the knowledge spiral. Socialization is tacit to tacit interaction, which is a process of sharing and converting tacit knowledge in order to create new tacit knowledge by connecting existing tacit knowledge with another tacit knowledge (Nonaka and Takeuchi, 1995; Song, 2008). Tacit knowledge is exchanged through joint activities with the aim of forming a mental model, metaphor, analogy or culture that is widely understood and serves as a framework for the next purposes (Nonaka and Konno, 1998).

The second interaction is called externalization, which is a pattern or process of tacit to explicit. This process is the process of converting tacit knowledge into explicit knowledge. Nonaka (1994) said that tacit knowledge within individuals can be articulated and conceptualized through creative dialogue that uses analogies, deductive reasoning, and metaphor in the dialogue. When tacit knowledge can turn into explicit then knowledge is said to be crystallized, so it allow to be used together and form the basis of new knowledge (Song, 2008).

The combination is a third pattern of interaction where existing explicit knowledge is converted into a more complex and systematic explicit knowledge, or explicit to explicit interaction (Nonaka and Takeuchi, 1995). In this process, there is a form reconfiguration by adding, selection, categorization or rewrites of existing knowledge that can lead to the creation of new knowledge. A last interaction pattern according to Nonaka (1994) is called internalization, which is the conversion of explicit knowledge back into tacit knowledge, or explicit to tacit interaction. This interaction occurs when individuals make the process of learning using the explicit knowledge that has been documented and then they formed a new understanding and experience within themselves. This process, according to Nonaka (1994), is the same thing as learning by doing activity or learning through practice.

These four patterns of interaction stated that the process of knowledge creation, particularly in the context of organization, involving a lot of activities. In socialization, for example, there is an activity of observation as part of the learning process so that the individual can acquire tacit knowledge from others. Similarly, in combination occurs rearranging or reconfiguring activities and utilization of existing explicit knowledge to create new knowledge (Popadiuk and Choo, 2006).

Each of these activities, essentially, is the processes of exploring and exploiting knowledge for specific purposes (Popadiuk and Choo, 2006). Observation activity is part of learning process that aims to explore or pursue new knowledge, in this case is tacit knowledge, to enrich existing 
knowledge. Similarly, in the combination, this process involves the use of or exploits existing knowledge to be developed into new knowledge.

Exploitation of knowledge according to March (1991) is the use and sustainable development over the existing competencies while the exploration of knowledge is defined as the pursuit of new competencies. In line with the opinion of March (1991), Sitkin et al. (1994) defines exploitation of knowledge as learning activities that include the use of resources already owned by the organization, as well as the exploration of knowledge as learning activities that lead to the addition of new resources. Both definition of March (1991) and Sitkin (1994) indicates that there are two basic modes for the production of knowledge in organizations, namely the exploitation or exploration of knowledge (Liu, 2006). The process of knowledge exploitation is basically the process of acquiring competence by adopting, integrating and applying existing knowledge. Therefore, this process requires the availability of knowledge that has been produced and used previously (Lyles and Schwenk, 1992). Type of exploitation activities by March (1991) are refinement, choice, production, efficiency, selection, implementation and execution which are aimed to enhancing the experience and reliability over existing knowledge. The results of these activities are the formation of small knowledge as additional knowledge with predictable implications.

In contrast to exploitation, exploration activity is the process of gaining competencies by acquiring knowledge that is completely new. March (1991) says that this process generally happen when an organization wants to gain experience through a variation in activities such as search, experimentation, invention, innovation, flexibility and risk taking. The result is new knowledge, different from the existing ones, having the possibility of high-potential and beneficial to the organization but with implications that cannot be predicted in advance.

For organizations, the exploration and exploitation of knowledge provide different benefits. Exploration of knowledge is useful in providing new knowledge and the level of freedom to adapt and thrive in a dynamic environment and making the organization more open to knowledge from outside (Land and Lubatkin, 1998). While the exploitation of knowledge enables organizations to transform and utilize the existing knowledge and make it absorbed into the system for optimized operations in order to increase performance (Liu, 2006).

In the process of exploration and exploitation of knowledge, the social network has been referred to as one of the factors that affect the search process and recombination of knowledge (Rotolo and Petruzzelli, 2012). This is due to the existence of a direct relationship with the other party would open up access to new information and stimulate the exchange of resources inherent in the relationship (McFadyen and Cannella, 2004; Nahapiet and Ghoshal, 1998).

Social networks developed through the interaction between the individual (or organization) and shared experiences between them (Rotolo and Petruzzelli, 2012). The more number of individuals involved in the network, the more information, ideas and resources contained therein. McFadyen and Cannella (2004) said that access to resources is very important for the process of knowledge creation because it will increase the likelihood of getting the specific resources needed to produce a new knowledge. The discovery of new knowledge in the realm of scientific research passed through a series of processes which include activities such as reading, writing, experiment, and interact with others, like fellow researchers (McFadyen and Cannella, 2004). Most of the knowledge used in the process of scientific research is a kind of knowledge that is complex, part of a particular scientific domain and involves a specific methodology. Information held are often tacit knowledge and can only be understood and combined by others who have a common language, knowledge and experience (Polanyi, 1966). Thus, the knowledge creation process then requires the various parties that have similarities to interact and share experiences, combining knowledge and solve problems through discussion, observation, and so on (Seufert et al., 1999, in McFadyen et al., 2004). Based on the discussion above, we propose hypotheses 1 as follows:

$\mathrm{H} 1 \mathrm{a}$ : Social network has a positive effect on knowledge exploitation

$\mathrm{H} 1 \mathrm{~b}$ : Social networks has a positive effect on knowledge exploration 
Funding is also referred to as one of the factors that affect the process of exploration and exploitation of knowledge. Johnes and Johnes (1995) in their study mentioned that funding has an important role in the research process. Funding in universities or research institutions can basically be classified into two: internal funding and external funding (Connolly, 1997). Although government funding is still a major source for college, but currently the industry funding has increased significantly. Scientists also have been aware that the grant of the industry is become an attractive funding source that is able to complement core funding sources and other public research funds (Hottenrott and Thorwarth, 2010). This funding factor, in addition to helping the individual or institution to be able to conduct research, meanwhile played a significant role in the behavioral research tendencies of individual or institution. This behavior is especially apparent in the selection of research themes, research methodology and results orientation which is whether pure or applied research (Benner and Sandström, 2000). Stokes (1997) defines a pure research (basic research) as a research conducted with the aim of developing a general knowledge and understanding of natural phenomena, without any practical purpose or application. While applied research is research that is intended for practical purposes (Stokes, 1997).

Referring to the definition of Stokes (1997), pure research is closer to the exploration of knowledge because understanding the phenomena involves the search process and the pursuit of new knowledge. Pure research generally use internal funding, because this kind of research emphasis on the discovery and exploration of new knowledge that is useful for improving the quality of education, promotion of the university as well as to gain recognition and dignity (Siadat et al., 2012). The research funded by external parties, especially the industry generally expected to adapt to the needs of the industry. Therefore, applicable knowledge is preferred so it can be applied by the industry as part of their innovation process (Hottenrott and Thorwarth, 2010). This kind of research is more close to the exploitation of existing knowledge which is include the selection process and improvements so it can be used for practical needs (Hottenrott and Lawson, 2012). Several earlier studies have been recognized the same thing. For example, studies of Gulbrandsen and Smeby (2005) that observed the researchers from universities in Norway and found that researchers are bound by industry funding were more likely to refer their research as applied research than researchers who are not bound by industry funding. A later study of Bozeman and Gaughan (2007) provides an analysis that there is a positive correlation between industry funding and the involvement of the industry into the domain of researchers to produce research that is more applied. Based on these explanations, we propose hypotheses 2 as follows:

$\mathrm{H} 2 \mathrm{a}$ : Funding has a positive effect on knowledge exploitation

$\mathrm{H} 2 \mathrm{~b}$ : Funding has a positive effect on knowledge exploration

Energy factor in the organization or by Schudy (2010) referred to as a productive organizational energy (EOP) has a close relationship with the activity of creation, exploitation and exploration of knowledge. EOP includes three dimensions, named affective dimension, cognitive dimension and behavioral dimension. Affective energy can contribute to the formation of the working atmosphere and the underlying collective inspiration and enthusiasm to the job duties. This will hone the creativity that leads to the discovery of new things (exploration) in the form of products, solutions or processes as well as digging the potential reuse of knowledge or resources that have been owned (exploitation) (Schudy, 2010).

Cognitive energy collectively form a system of thinking among members of the organization to find solutions to problems related to the job duties. The system of collective thinking is fundamentally leads to two things: the first focuses on the problems faced now and how to utilize available resources to solve them. The second is pro-active thinking to come up with new ideas that can be the basis for the creation of new knowledge, if it finds that available resources are no longer sufficient to solve the problem (Schudy, 2010; Cole et al., 2012). 
Behavioral energy is the system to facilitate the establishment of communication, collaboration and resource sharing among members of the organization which lead to the improvement of the quality of relationships between individuals. New knowledge is sometimes created through the complex organizational behavior such as integrated communication and collective action (Schudy, 2010; Huy, 2002). Based on the explanation above, we propose the following hypotheses:

$\mathrm{H} 3 \mathrm{a}$ : Productive organizational energy has a positive effect on knowledge exploitation $\mathrm{H} 3 \mathrm{~b}$ : Productive organizational energy has a positive effect on knowledge exploration

According to Holmqvist (2004), the exploration and exploitation is a learning process depend on each other. Exploitation of existing knowledge often requires exploration of new capabilities and the exploration of new capabilities also enhance the existing knowledge (Katila and Ahuja, 2002). Although exploration is a prerequisite for exploitation, but the benefits of exploration is also depend on the amount of knowledge that has been accumulated and studied through exploitation. Thus, although the process of exploration and exploitation is carried out separately, but continue to interact.

In the process of learning, Crossan et al. (1999) asserts that not only learning must happen all the time and at all levels, but also creates a contradiction between generating new knowledge to obtain the feed forward and to exploit and use existing knowledge to get feedback. Achieving a balance mechanism proposed by previous research is ambidexterity (Gupta et al., 2006). Ambidexterity encourages organizations to provide relatively equal emphasis on the process of exploration and exploitation (He and Wong, 2004). From the perspective of learning, ambidexterity is important because the process of exploration and exploitation is very crucial for the creation and dissemination of knowledge that should be performed simultaneously (Ahuja and Lampert, 2001).

There are two major types of ambidexterity in the organizational context, named structural ambidexterity and contextual ambidexterity (Schudy, 2010). Structural ambidexterity achieved by building different units, then each of this focuses on the exploitation or exploration. While contextual Ambidexterity achieved not by manage of different units, but on how to design the organization in order to encourage and enable all individuals in it in order to make their own decisions related to devote time to conduct exploration or exploitation (Gibson and Birkinshaw, 2004). Based on explanation the benefits of exploration and exploitation activities for the survival of the organization, as well as the importance of developing the ability to balance these two activities, we propose the following hypotheses:

$\mathrm{H} 4 \mathrm{a}$ : Exploration has a positive effect on organizational Ambidexterity

$\mathrm{H} 4 \mathrm{~b}$ : Exploitation has a positive effect on organizational Ambidexterity

\section{Research Methods}

The Model

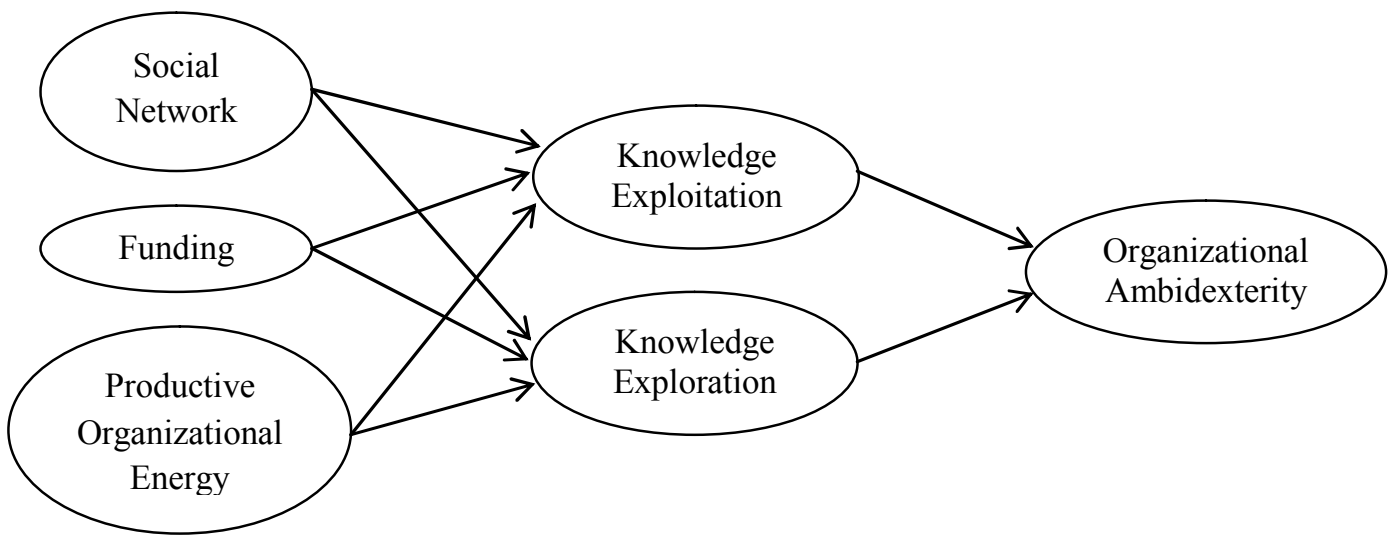

Figure 1. Research Model 
The model in this study, as shown in Figure 1, depicts the three independent variables, named social networking, funding and productive organizational energy has a positive effect on knowledge exploration and knowledge exploitation. Then the knowledge exploration and knowledge exploitation as the independent variable has a positive effect on organizational ambidexterity as the dependent variable.

\section{The Sampling Process}

Sampling in this study is collected using a non-probability approach with purposive judgment sampling method. Respondents for this research are research institutions in the form of laboratory, training centers or study centers owned by the university in Yogyakarta, which is active in doing research and training within the last three years. The three types of institutions are assumed to be actively involved in knowledge exploration and knowledge exploitation activities in producing outputs, for example in the form of publications or training materials. Data was collected through questionnaires, distributed directly to the institution concerned.

The amounts of 130 respondents are successfully collected from six universities in Yogyakarta. The majority of respondents or similarly as 74.62 percent is dominated by the laboratory. The majority of respondents or similarly as 82.30 per cent comes from the field of science. The number of staff per research institution is ranging from 2 to 10 people with a percentage of 77.70 percent. For composition of funding, the majority of research institutions are funded by internal funding such as university and faculty with a percentage of 65.38 per cent.

\section{The Measurements}

Measurement of variables in this study adapted from research instruments that have been used by previous studies. Constructs of social networks was measured with 15 questions adapted from YliRenko et al. (1993) and Gulbrandsen and Smeby (2005). Constructs of funding was measured with 5 questions adapted from research Gulbrandsen and Smeby (2005). Productive organizational energy constructs has three dimensions, which are affective energy dimensions, cognitive energy dimension and behavioral energy dimensions. Measurement of these constructs using a total of 14 questions from Cole et al. (2005), comprising 5 questions for the affective dimension, 5 questions to cognitive dimension and 4 questions for behavioral dimension.

Knowledge exploitation and knowledge exploration construct was measured by 5 questions each and adapted from Zahra et al. (2000). Organizational ambidexterity constructs was measured using 6 questions from Gibson and Birkinshaw (2004). All questions and statements are measured using a Likert scale of 1 to $5(1=$ no/never at all/strongly disagree to $5=$ a great deal/very often/strongly agree).

Based on the result of convergent validity test (using a minimum value limit loading factor of 0.5), discriminant validity (using a limit of root AVE values greater than the value of the correlation between variables) and reliability test (using Cronbach's Alpha and Composite Reliability values), from 52 questions of measurements, 38 questions are proved valid and reliable. The entire test validity, reliability and hypotheses performed using analysis tools Partial Least Square (PLS) with program SmartPLS version 2.0. Validity and reliability of the results are presented in Tables 1, 2 and 3.

Based on Table 1 and Table 3, it can be seen that the social network variable (JS) had 9 points that valid and reliable with Cronbach's Alpha value of 0.842 . Funding variable (PD) has 3 points that valid and reliable with Cronbach's Alpha value of 0.758 . Productive organizational energy variable (EOP) has 11 items that valid and reliable with Cronbach's Alpha value of 0.889 . Knowledge exploitation variable (EIP) and knowledge exploration variable (ERP) has 6 measurement points for each are valid and reliable with Cronbach's Alpha value of 0.936 and 0.931 . For organizational ambidexterity variable $(\mathrm{OA})$, there are 3 points that valid and reliable with Cronbach's Alpha value of 0.674 . 
Table 1. Convergent Validity Testing Results

\begin{tabular}{lccc}
\hline \multicolumn{1}{c}{ Variables } & \multirow{2}{*}{ Item } & \multicolumn{2}{c}{ Convergent Validity } \\
\hline & & Factor Loading & AVE \\
\hline Social Network (JS) & 9 & $0,548-0,760$ & 0,437 \\
Funding (PD) & 3 & $0,605-0,923$ & 0,671 \\
Productive Organizational Energy (EOP) & 11 & $0,547-0,774$ & 0,464 \\
Knowledge Exploitation (EIP) & 6 & $0,800-0,908$ & 0,760 \\
Knowledge Exploration (ERP) & 6 & $0,845-0,885$ & 0,742 \\
Organizational Ambidexterity (OA) & 3 & $0,635-0,895$ & 0,596 \\
\hline
\end{tabular}

Table 2. Discriminant Validity Testing Results

\begin{tabular}{ccccccccr}
\hline Variables & Root of AVE & EIP & EOP & ERP & JS & OA & PD \\
\hline EIP & 0,873 & & 1 & & & & & \\
EOP & 0,682 & 0,495 & & 1 & & & & \\
ERP & 0,862 & 0,837 & 0,421 & & 1 & & & \\
JS & 0,661 & 0,685 & 0,586 & 0,662 & & 1 & & \\
OA & 0,773 & 0,670 & 0,713 & 0,630 & 0,634 & & 1 & \\
PD & 0,820 & 0,663 & 0,603 & 0,587 & 0,611 & 0,731 & 1 \\
\hline
\end{tabular}

Table 3. Reliability Testing Results

\begin{tabular}{lcc}
\hline \multicolumn{1}{c}{ Variables } & Composite Reliability & Cronbach's Alpha \\
\hline Social Network (JS) & 0,873 & 0,842 \\
Funding (PD) & 0,856 & 0,758 \\
Productive Organizational Energy (EOP) & 0,904 & 0,889 \\
Knowledge Exploitation (EIP) & 0,950 & 0,936 \\
Knowledge Exploration (ERP) & 0,945 & 0,931 \\
Organizational Ambidexterity (OA) & 0,813 & 0,674 \\
\hline
\end{tabular}

Table 2 shows that the value of the roots of AVE is greater than the entire value of the latent variable correlation of knowledge exploitation construct, knowledge exploration construct, productive organizational energy, funding and organizational Ambidexterity. Except in the construct of social networks, the value of the root of AVE is slightly smaller than the value of the variable correlation of knowledge exploitation and knowledge exploration. However, it can be ignored because the value of factor loading indicator of the variable is still above 0.5 and the indicators still accumulate in the constructs that represent them. It can conclude that all variables under study have met the discriminant validity.

\section{Results and Discussion}

Accuracy test of models in PLS were evaluated using the R-square for the dependent variable, and the value of beta coefficient $(\beta)$ on a path for the independent variables, then assessed its significance based on the value of the t-statistic. R-square values indicate the magnitude of the percentage of the total variance of the independent variable (exogenous) to explain the dependent variable (endogenous) (Hair et al., 2006). The results of model testing can be seen in Table 4.

Table 4. Model Testing

\begin{tabular}{lc}
\hline \multicolumn{1}{c}{ Variables } & $R$ Square \\
\hline Knowledge Exploitation (EIP) & 0,565 \\
Knowledge Exploration (ERP) & 0,494 \\
Organizational Ambidexterity (OA) & 0,465 \\
\hline
\end{tabular}


From the R-square value, it can be seen that the ability of the independent variables (social network, funding and productive organizational energy) to explain the dependent variable of knowledge exploitation are 56.5 percent and explain the dependent variable of knowledge exploration are 49.4 percent, the rest is explained by other variables or other factors. While the variable of knowledge exploitation and knowledge exploration in explaining the dependent variable of organizational ambidexterity are 46.5 percent, then the rest is explained by other variables outside the model.

To test the hypotheses, analysis of causal relationships between variables can be checked by the path coefficient values or t-values of each path. Scores of path coefficients indicated by the value of t-statistics should be above 1.64 for one-tailed hypothesis at $5 \%$ alpha (Hair et al., 2006). The results of hypothesis testing can be seen in Table 5 below.

Table 5. Hypothesis Testing Result

\begin{tabular}{clccccc}
\hline Hypotheses & $\begin{array}{c}\text { Causal } \\
\text { Relationship }\end{array}$ & $\begin{array}{c}\text { Original } \\
\text { Sample }\end{array}$ & $\begin{array}{c}\text { Standard } \\
\text { Error }\end{array}$ & $\begin{array}{c}\mathrm{t} \text { - } \\
\text { Statistics }\end{array}$ & $\begin{array}{c}\mathrm{t}- \\
\text { Table }\end{array}$ & Results \\
\hline H1a & JS $\rightarrow$ EIP & 0,447 & 0,078 & $5,727^{*}$ & 1,64 & Supported \\
H1b & JS $\rightarrow$ ERP & 0,507 & 0,122 & $4,138^{*}$ & 1,64 & Supported \\
H2a & PD $\rightarrow$ EIP & 0,391 & 0,089 & $4,355^{*}$ & 1,64 & Supported \\
H2b & PD $\rightarrow$ ERP & 0,317 & 0,112 & $2,828^{*}$ & 1,64 & Supported \\
H3a & EOP $\rightarrow$ EIP & $-0,002$ & 0,076 & 0,038 & 1,64 & Not Supported \\
H3b & EOP $\rightarrow$ ERP & $-0,067$ & 0,093 & 0,722 & 1,64 & Not Supported \\
H4a & EIP $\rightarrow$ OA & 0,479 & 0,127 & $3,764^{*}$ & 1,64 & Supported \\
H4b & ERP $\rightarrow$ OA & 0,228 & 0,137 & $1,660^{*}$ & 1,64 & Supported \\
\hline
\end{tabular}

Table 5 indicates that six of the eight hypotheses showed significant results. A social network is proven to have a positive influence on knowledge exploitation and knowledge exploration. Funding is also proven to have the positive influence on knowledge exploration and knowledge exploitation, as well as knowledge exploitation and knowledge exploration on organizational Ambidexterity. Otherwise, productive organizational energy is not proven to have positive influence on knowledge exploitation and knowledge exploration.

The findings of this study confirm that social networks owned by research institutions were able to significantly affect the exploitation of knowledge (EIP) and the exploration of knowledge (ERP). These results are supported by several previous studies such as Chua (2002), McFadyen and Cannella (2004), Siadat et al., (2012), revealed that social interactions affect the knowledge creation. According to Chua (2002) social interaction can provide a broader access to the resource that valuable and useful for the creation of knowledge.

These results are also in accordance with the opinion of McFadyen and Cannella (2004) and Rotolo and Petruzzelli (2012) which says that the strength of the relationship with the other party is very important for the process of knowledge creation and the improvement of social relationships will open up wider opportunities for recombination of knowledge and provide a better position for the dissemination of knowledge. Knowledge creation, as described in research of Popadiuk and Choo (2006) is a process that is closely associated with the exploration and exploitation activities. Thus, the previous research results of the social network effects on knowledge creation are in line with the results of this study which demonstrate the effect of social networks on the exploration and exploitation of knowledge.

In addition, funding that obtained by research institutions significantly affect the exploitation of knowledge (EIP) and the exploration of knowledge (ERP). The study of Connolly (1997), Auranen and Nieminen (2010), Hottenrott and Thorwarth (2010) and Hottenrott and Lawson (2012) have shown that funding is an important factor for research in research institutions to create knowledge. The findings of this study support that funding can influence the exploration and exploitation of knowledge related to knowledge creation. Composition of funding in this study is dominated by 
internal funding by the amount of 65.38 per cent. From this composition, as claimed by Connolly (1997) research institutions should doing more exploration activities to produce more pure knowledge. However, the t-statistic indicates the number of exploitation (EIP) is greater than exploration (ERP). Thus, it is likely that research institutions studied tend to perform more knowledge exploitation activities than knowledge exploration, with the exclusion of funding whether it is obtained from internal or external.

The results of this study support that the exploitation and exploration of knowledge are contribute to form the capability of organizational ambidexterity and this is most likely because exploration and exploitation is a primary factor to form such capabilities. However, t-statistics value shows that the numbers for the exploitation of knowledge quite different from the exploration of knowledge. It is informed that the balances of the two activities are not achieved yet. In other words, research institutions studied still more doing the exploitation activities than the exploration. More clearly it can be said that research institutions investigated here are yet become an ambidextrous institution.

The study also found that the productive organizational energy is not significantly affected the knowledge exploitation (EIP) and knowledge exploration (ERP). Productive organizational energy is a multidimensional mechanism where inter correlation of each dimension (affective, cognitive and behavioral) are believed to affect the productivity and performance of the organization (Schudy, 2010). Research from Schudy (2010) provide an empirical evidence that productive organizational energy has a positive effect on organization performance and serves as underlying mechanisms of the relationship between contextual ambidexterity and organization performance. However, the results of this study do not support it. The findings of this study indicate that the productive organizational energy is not significantly influence the exploration and exploitation of knowledge in research institution. These different results may be related to different research contexts. Schudy (2010) conducted a study on 71 commercial enterprises from various industries with an average number of employees is 130 . While this study was conducted at research institutions with the largest percentage of employees are under 10. Assumed that this construct is a construct that measures about employee engagement, then the difference amount of employees will certainly affect the study results. However, this conclusion still needs to be proven through future studies.

\section{Conclusion and Future Direction}

The study proof that social network and funding influence knowledge exploration and exploitation. However, productive organizational energy has no positive effect on knowledge exploration and knowledge exploitation. It is also confirmed that knowledge exploration and exploitation have a significant influence on the capability of organizational ambidexterity, but knowledge exploitation has a dominant role on that effect.

This study used a relatively small sample only from one region thus limiting generalizability of study results. In addition, the study was conducted at one point in time so it was not so good at capturing changes in the structure of social networks, the composition of funding and increased or decreased activity of the exploration and exploitation of knowledge. Future studies are expected to be able to use a larger sample size with a wider range of areas and should be conducted longitudinally in order to give a better explanation of the phenomenon under study. Continuous research needs to be done to ensure the relevance of research results in order to reflect the development of knowledge exploration and exploitation activities in the organization and its contribution to the development of organizational ambidexterity capabilities.

\section{References}

Adler, P., Goldoftas, B., \& Levine, D. (1999). Flexibility versus efficiency: A case study of model changeovers in the Toyota production system. Organization Science, 10, 43-68. 
Ahuja, G., \& Lampert, C. (2001). Entrepreneurship in the large corporation: A longitudinal study of how established firms create breakthrough inventions. Strategic Management Journal, 22, 521-543.

Ambos, T., Makela, K., Birkinshaw, J., \& D'Este, P. (2008). When does university get commercialized? Creating ambidexterity in research institutions. Journal of Management Studies, 45(8), 1424-1447.

Andriopoulos, C., \& Lewis, M. (2009). Exploitation-Exploration Tensions and Organizational Ambidexterity: Managing Paradoxes of Innovation. Organization Science, 204), 696-717.

Auranen, O., \& Nieminen, M. (2010). University Research Funding and Publication Performance An International Comparison. Research Policy, 39(6), 822-834.

Barney, J. (1991). Firm Resources and Sustained Competitive Advantage. Journal of Management, 17(1), 99-120.

Benner, M., \& Sandström, U. (2000). Institutionalizing the triple helix: research funding and norms in the academic system. Research Policy, 29(2), 291-301.

Benner, M., \& Tushman, M. (2003). Exploitation, Exploration and Process Management: The Productivity Dilemma Revisited. Academy of Management Review, 28(2), 238-256.

Bozeman, B., \& Gaughan, M. (2007). Impacts of Grants and Contracts on Academic Researchers' Interactions with Industry. Research Policy, 36, 694-707.

Brass, D., \& Burkhardt, M. (1993). Potential power and power use: An investigation of structure and behavior. Academy of Management Journal, 36(3), 441-470.

Carayol, N., \& Matt, M. (2006). Individual and collective determinants of academic scientists productivity. Information Economics and Policy, 18(1), 55-72.

Cegarra-Navaro, J., Sanchez-Vidal, M., \& Cegarra-Leiva, D. (2011). Balancing exploration and exploitation of knowledge through an unlearning context. Management Decision, 49(7), 10991119.

Chang, Y., Yang, P., \& Chen, M. (2009). The determinants of academic research commercial performance: Towards an organizational ambidexterity perspective. Research Policy, 38(6), 936-946.

Chin, W. (1995). Partial least square is to LISREL as principal components analysis is to common factor analysis. Technology Studies, 2, 315-319.

Cohen, S., \& Bailey, D. (1997). What makes teams work: Group effectiveness research from the shop floor to the executive suite. Journal of Management, 23, 239-290.

Cohen, W., \& Levinthal, D. (1990). Absorptive Capacity: a new perspective on learning and innovation. Administrative Science Quarterly, 35, 128-152.

Cohen, W., Nelson, R., \& Walsh, J. (2002). Links and impacts: the influence of public research on industrial R\&D. Management Science, 48, 1-23.

Cole, M., Bruch, H., \& Vogel, B. (2012). Energy at work: A measurement validation and linkage to unit effectiveness. Journal of Organizational Behavior, 33, 445-467.

Connolly, L. (1997). Does external funding of academic research crowd out institutional support? Journal of Public Economics, 64, 389-406.

Cooper, R., \& Schindler, S. (2011). Business Research Method(11th ed.). USA: McGraw Hill.

Crossan, M., Lane, H., \& White, R. (1999). An organizational learning framework: from intuition to institution. Academy of Management Review, 24(3), 522-537. 
Dutton, J. E. (2003). Energize Your Workplace: How to Create and Sustain High-Quality Connections at Work. San Francisco, CA: Jossey-Bass.

Gibson, C., \& Birkinshaw, J. (2004). The Antecedents, Consequences and Mediating Role of Organizational Ambidexterity. Academy of Management Journal, 47(2), 209-226.

Gulati, R., Nohria, N., \& A, Z. (2000). Strategic Networks. Strategic Management Journal, 21(3), 203-215.

Gulbrandsen, M., \& Smeby, J. (2005). Industry funding and university professors research performance. Research Policy, 34, 932 - 950.

Gupta, A., Smith, K., \& Shalley, C. (2006). The interplay between exploration and exploitation. Academy of Management Journal, 4, 693-706.

Guttel, W., \& Konlechner, S. (2009). Continuously hanging by a thread: Managing contextually ambidextrous organizations. Schmalenbach Business Review, 150-172.

Hair, J., Joseph, F., Black, W., Babin, B., \& Anderson, R. (2006). Multivariate Data Analysis (6th ed.). USA: Pearson.

Hartono, J. (2011). Konsep dan Aplikasi Structural Equation Modeling Berbasis Varian dalam Penelitian Bisnis. Yogyakarta: UPP STIM YKPN.

Hartono, J., \& Abdillah, W. (2009). Konsep aplikasi PLS untuk penelitian empiris. Yogyakarta: BPFE UGM.

He, Z., \& Wong, P. (2004). Exploration vs. exploitation: An empirical test of the ambidexterity hypothesis. Organization Science, 15, 481-494.

Hofmann, D., \& Jones, L. (2005). Leadership, Collective Personality, and Performance. Journal of Applied Psychology, 90(3), 509-522.

Holmqvist, M. (2004). Experiential learning processes of exploitation and exploration: an empirical study of product development. Organization Science, 15(1), 70-81.

Hottenrott, H., \& Lawson, C. (2012). Research Grants, Sources of Ideas and the Effects on Academic Research. Mannheim, Germany: Centre for European Economic Research (ZEW).

Hottenrott, H., \& Thorwarth, S. (2010). Industry Funding of University Research and Scientific Productivity. Mannheim, Germany: Centre for European Economic Research (ZEW).

Huy, Q. (2002). Emotional Balancing of Organizational Continuity and Radical Change: The Contribution of Middle Managers. Administrative Science Quarterly, 47(1), 31-69.

Johnes, J., \& Johnes, G. (1995). Research Funding and Performance in U.K. University Departments of Economics: A Frontier Analysis. Economics of Education Review, 14(3), 301-314.

Katila, R., \& Ahuja, G. (2002). Something old, something new: A longitudinal study of search behavior and new product introduction. Academy of Management Journai, 45(6), 1183-1194.

Katz, J., \& Martin, B. (1997). What is research collaboration? Research Policy, 26(1), 1-18. Kogut, B., \& Zander, U. (1992). Knowledge of the firm, combinative capabilities and the replication of technology. Organization Science, 3, 383-397.

Lam, A. (2000). Tacit Knowledge, Organizational Learning and Societal Institutions: An Integrated Framework. Organization Studies, 21(3), 487-513.

Land, P., \& Lubatkin, M. (1998). Relative absorptive capacity and inter-organizational learning. Strategic Management Journal, 19, 461-477.

Levinthal, D., \& March, J. (1993). Myopia of Learning. Strategic Management Journal, 14, 95-112. 
Liu, W. (2006). Knowledge Exploitation, Knowledge Exploration and Competency Trap. Knowledge and Process Management, 13(3), 144-161.

Lyles, M., \& Schwenk, C. (1992). Top management, strategy and organizational knowledge structures. Journal of Management Studies, 29, 155-174.

March, J. (1991). Exploration and Exploitation in Organizational Learning. Organization Science, 2(1), 71-87.

McFadyen, M., \& Cannella, A. (2004). Social Capital and Knowledge Creation: Diminishing Returns of the Number and Strength of Exchange. Academy of Management Journal, 47(5), 735746.

Melin, G., \& Persson, O. (1996). Studying research collaboration using co-authorship. Scientometrics, 36(3), 363-377.

Mohnen, P., \& Hoareau, C. (2002). What type of enterprise forges close links with universities and government labs? Evidence from CIS 2. Managerial and Decision Economics, 24, 133-145.

Nahapiet, J., \& Ghoshal, S. (1998). Social Capital, Intellectual Capital, and the Organizational Advantage. Academy of Management Review, 23(2), 242-266.

Nonaka, I. (1994). A Dynamic Theory of Organizational Knowledge Creation. Organization Science, 5(1), 14-37.

Nonaka, I., \& Konno, N. (1998). The concept of "ba": Building a foundation for knowledge creation. California Management Review, 40(3), 40-54.

Nonaka, I., \& Takeuchi, H. (1995). The Knowledge Creating Company. New York: Oxford University Press.

Polanyi, M. (1966). The Logic of Tacit Inference. Philosophy, Vol. 41, No. 155, 1-18.

Popadiuk, S., \& Choo, C. (2006). Innovation and Knowledge Creation : How are these concepts related? International Journal of Information Management, 26, 302-312.

Prahalad, C., \& Hamel, G. (1990). The core competence of the corporation. Harvard Business Review, 68, 79-91.

Quinn, R., \& Dutton, J. (2005). Coordination as Energy-in-Conversation. Academy of Management Review, 30(1), 36-57.

Raisch, S., \& Birkinshaw, J. (2008). Organizational Ambidexterity: Antecedents, Outcomes and Moderators. Journal of Management, 34(3), 375-409.

Ramirez, A., Morales, V., \& Aranda, D. (2012). Knowledge Creation and Flexibility of Distribution of Information. Industrial Management \& Data Systems, 112(2), 166-185.

Rotolo, D., \& Petruzzelli, A. (2012). When Does Centrality Matter? Scientific Productivity and the Moderating Role of Research Specialization and Cross Community Ties. Journal of Organizational Behavior (forthcoming), 1-48.

Rynes, S., Bartunek, J., \& Daft, R. (2001). Across the Great Divide: Knowledge Creation and Transfer between Practitioners and Academics. Academy of Management Journal, 44(2), 340355.

Schudy, C. (2010). Contextual Ambidexterity in Organizations: Antecedents and Performance Consequences. Switzerland: University of St. Gallen.

Selnes, F., \& Sallis, J. (2003). Promoting relationship learning. Journal of Marketing, 67(3), 80-95.

Siadat, S., Hoveida, R., Abbaszadeh, M., \& Moghtadaie, L. (2012). Knowledge Creation in Universities and Some Related Factors. Journal of Management Development, 31(8), 845-872. 
Sitkin, S., Sutcliffe, K., \& Schroeder, R. (1994). Distinguishing control form learning in total quality management; A contingency perspective. Academy of Management Review, 19, 537-564.

Smith, W., \& Tushman, M. (2005). Managing strategic contradictions: A top management model for managing innovation streams. Organization Science, 16, 522-536.

Song, J. (2008). The Integrative Determinants of Organizational Performance Improvement: The Impact of Dimensions of Learning Organization and Dynamic Knowledge Creation. Pennsylvania, USA: Pennsylvania State University.

Stokes, D. (1997). Pasteur's quadrant: Basic science and technological innovation. Washington, DC: Brookings Institution Press.

Tempelaar, M. (2010). Organizing for Ambidexterity. Rotterdam: Erasmus University. Trieschmann, J., Dennis, A., Northcraft, G., \& Niemi, A. (2000). Serving Multiple Constituencies

in the Business School: MBA Program vs. Research Performance. Academy of Management Journal (In Press), 1-27.

Tushman, M., \& O'Reilly, C. (1996). Ambidextrous organizations: Managing evolutionary and revolutionary change. California Management Review, 38, 8-30.

Yamin, S., \& Kurniawan, H. (2011). Generasi Baru Mengolah Data Penelitian dengan Partial Least Square Path Modeling. Jakarta: Salemba Infotek.

Ynalvez, M., \& Shrum, W. (2011). Professional networks, scientific collaboration, and publication productivity in resource-constrained research institutions in a developing country. Research Policy, 4O(2), 204-216.

Zaheer, A., \& Bell, G. (2005). Benefiting from network position: firm capabilities, structural holes, and performance. Strategic Management Journal, 26(9), 809-825. 